\title{
Legal Crime Investigation Cases of Oil And Gas Transportation (BBM) in Polres Purworejo
}

\begin{abstract}
Khusen Martono ${ }^{1}$ and Gunarto ${ }^{2}$
Abstract. The development of motor vehicles in Indonesia, particularly the development of two-wheel motor vehicles makes the supply of fossil fuels is increasing. The high fuel makes the fuel supply to the higher regions of Pertamina. Pertamina fuel supply in this area through a gas station (Fuel Filling Station General). This gas station into a formal point or an agent authorized to distribute fuel Pertamina to society. Criminal act of transporting fuel oil / fuel are subject to review of some aspects of the law to obtain justice. During these criminal cases haulage fuel seek of formal legal aspects applicable law, but a criminal act can not be seen from one side, but from some vantage as regional aspects and the economic aspects. The principle of legal justice that offers solutions to the public should be considered, although there is a violation of rules that apply in this transport process. Legal clash between the needs of society with Section 53 letters $b$ and $d$ of Republic Act number 22 of 2001 on oil and gas must have an alternative way out of sync between a solution and the rule of law.

Keywords: BBM; Criminal; Justice; Law.
\end{abstract}

\section{Introduction}

Oil and gas is a natural resource that is controlled by the state and has an important role in the national economy that must be managed optimally as possible. In an effort to create business activities of oil and natural gas in order to realize increased prosperity and welfare of the people has been set Act No. 22 of 2001 on Oil and Gas. These laws provide a legal basis for the renewal and restructuring of the oil and gas business activities. This law regulates the business activities associated with oil and gas, both upstream activities and downstream activities.

Downstream activities business activities focused or based on the business activities of processing, transport, storage and / Commerce. Business Activity Commercial General is the business activities of the sale, purchase, export and import of fuel oil, fuel gas, other fuels and / or processed in large-scale controls or have facilities and storage facilities and the right channel to all end users to use the trademark or more often certain we know is the pump. However, there are also individual types of business in the context of selling retail trade / retailer of fuel they buy the fuel oil at the pump.

In carrying out the activities of the provision and distribution of fuel from gas stations to retail distribution of fuel irregularities. This deviation is part of a criminal act that should be prosecuted by the authorities. Issues raised in this paper is the investigation of criminal cases that occurred in the transport fuel Purworejo district police are still using the formal legal laws, Act No. 22 of 2001 on Oil and Gas and have not seen justice aspects of the law (and the economic aspects of the region) community.

\section{Research Methods}

This study is an empirical law of the type of research that is based on the study of the

\footnotetext{
${ }^{1}$ Student of Master of Law, Universitas Islam Sultan Agung Semarang and Police email nobitadi@gmail.com

${ }^{2}$ Professor of Faculty of Law UNISSULA Semarang
} 
workings of law in society. Working of the law in society can be assessed the effectiveness of law. ${ }^{3}$ The nature of research is descriptive, studies conducted to obtain data, facts of phenomena that exist and seek factual particulars on the data concerning the crime of abuse of the transport of fuel oil (BBM). Descriptive research is research conducted to obtain data, facts of phenomena that exist and seek factual particulars on the data concerning the investigation of criminal abuse of the transport of fuel oil (BBM) in Purworejo.

Approach in research this is socio-juridical. Legal research juridical sociological research that examines the behavior of people who interact with the system arising from the existing norms. Interaction emerged as a form of public reaction on applied a provision of positive law invitation and can also be seen from the behavior of society as a form of action in influencing the formation of a positive legal statutory provisions and can also be seen from the behavior of society as a form of action in influencing the formation of a provision of positive law. ${ }^{4}$

\section{Results and Discussion}

The focus in this paper is the transport / commercial fuel from gas station to gas station the lower level or min / retailer. Transportation is loading activities of passengers or goods into a conveyance, transfer of passengers or goods the place of destination by the transporter, and the decrease in passengers or unloading of transporters at the agreed destination. Transporting function is to move goods or people from one place to another with the intent to improve the usability and value ${ }^{5}$, Freight / commercial fuel from gas stations to the lower level or the gas station mini / retailers during this time, the criminal act of transport has been investigated and punished by the authorities. The main problem of this criminal act is the absence of the possession permit the transport of the gas station mini business owners / retailers.

The analogy of this case consists of crime, transporting permits, specifications mini petrol stations, transport and transport security needs of the community. Criminal act of transporting fuel oil / fuel are subject to review of some aspects of the law to obtain justice. During these criminal cases haulage fuel seek of formal legal aspects applicable law, but a criminal act can not be seen from one side, but from some vantage sudat as regional aspects and the economic aspects. Inside this discussion will analyze the crime of transporting the fuel through the analysis of case law sanctions and analysis of legal justice.

\subsection{Enforcing Case Analysis of Fuel Transportation Crime}

Transportation activities are not accompanied by consent is a criminal offense. Definition of a criminal offense is prohibited by a rule of law, a ban which accompanied certain criminal sanctions in the form to any person who violates these rules. It can also be said that the criminal act is prohibited by law and punishable if only in that it caused by the behavior of people, being criminal threat aimed at the people who caused the crime ${ }^{6}$. The transport of fuel contained in Act No. 22 of 2001 on Oil and Gas. According to Act No. 22 of 2001 on Oil

\footnotetext{
${ }^{3}$ Salim HS dan Erlies Septiana Nurbani 2013 Penerapan Teori Hukum Pada Penelitian Penelitian dan Disertasi. Jakarta: PT Raja Grafindo Persada p 20

${ }^{4}$ Mukti Fajar dan Yulianto Achmad 2010 Dualisme Penelitian Hukum Penelitian Normatif \& Empiris Yogyakarta: Pustaka Pelajar p 51

${ }^{5}$ Soegijatno Tjakranegara 1995 Hukum Pengangkutan Barang dan Penumpang Rineka Cipta : Jakarta p. 1

${ }^{6}$ Moeljatno,L. 2015. Asas-asas Hukum Pidana. Rineka Cipta : Jakarta p 140
} 
and Gas Article 23 paragraph (1) explained that the downstream activities carried out by business entities must obtain a business license from the government which includes: transport, trade, processing, and storage of fuel.

Article 53 of Act No. 22 of 2001 "that anyone conducting business: Transport as in Article 23 without a business license conveyance shall be punished with imprisonment for a period of 4 (four) years and a fine of Rp. 40.000.000.000,00- (forty billion rupiah); The elements of the crime of transporting in Article 53 (b) of Act No. 22 of 2001 on oil and gas consists of: 1) Each person; 2) Transporting; 3) Without the permission of the transport business.

Deeds done in this article is any person or entity conducting the transfer of fuel from one place to another without their consent transportation business. Weigh that prior to admission to the consideration of the elements in question, the panel will explore what is meant by abuse, misuse words in Act No.22 of 2001 are activities aimed to gain individual or business entity to the detriment of public interests and countries such as, among others, the mixing action of fuel oil, fuel oil allocation irregularities, Transportation and Sale of Fuel abroad (article 55 of Law Company - Oil and Natural Gas Act);

Freight carried entrepreneurs gas station mini / retailer is a non-subsidized fuel. TypeBBMthatnot subsidized by the government is fuelthatsubsidizedThe government is Fuelyangbe regulatedin the regulation as stipulated in Presidential Decree No. 71 of 2005 which has been converted into number 1912014 About Supply and Distribution of Fuel Type Certain.

BBM non-subsidized typepertamax,dex pertalite and diesel fuel intended for all pengfor fuelasdala attachment set rules president No. 15 of 2012 that into numbers 191 of 2014 and regulation Minister ESDM Number 18 of 2013 about consumer of particular fuel.

Prosedur distribution of fuelwho does notsubsidized Government that is by Public Service Obligasi (PSO) assigned PT. Pertamina (Persero) and ascompanion PT. Aneka Kimia Raya (AKR) which further Enterprises General Trading Enterprises (BUPIUNU) be appointed may appoint a distributor as regulated in Article 69 of Government Regulation No. 36 of 2004 on Oil and Gas down stream activities such as: gas stations, SPBB, APMS, SPDN while for large orders can order directly to Pertamina and AKR.

Communities can buy fuel that is not subsidized kind pertamax, pertalite and diesel dex can be purchased at the handover point is the gas station,APMS, SPBN, SPBB while for large orders can order directly to Pertamina and AKR. It is set in the annex Presidential Regulation No. 15 of 2012 and Regulation of the Minister No. 18 of 2013 concerning the retail selling price and consumer use of certain types of fuel.

BBM is not subsidized as defined in Article 2 and 3 of Presidential Regulation Number 15 of 2012 that are eligible for non-subsidized fuel is all the people who use the fuel and the amount is not limited andentitled to transport fuel is not subsidized entity that has been appointed by the government based on partnership agreements that the fleet (conveyance) shall be registered with the BUPIUNU to distribute fuel is not subsidized by appointing distributors as both a transporter and as agent bunker fuel is not subsidized.

Procedures for commercial fuel is not subsidized suppliers are not given a quota to distribute fuel is not subsidized to the final consumer (listed in Presidential Decree No. 15 of 2012 and the Regulation of the Minister of Energy and Mineral Resources No. 18 of 2013 concerning the retail selling price and consumer peguan certain types of fuel) which price the oil selling to the final consumer in accordance with the value set by the government and the right to distribute or sell the fuel is not subsidized pertamax,peralite and diesel suppliers dex is that 
the pump, SPBN, APMS, SPBB and agents bunker other (Presidential Decree No. 15 of 2012, which has been converted into number 191 of 2014 and the Regulation of the Minister of Energy and Mineral Resources No. 18 of 2013 concerning the retail selling price and the consumer the User certain types of fuel) and the witness stated that to permit the transport and or commercial fuel is not subsidized Minister through the Director General of oil and Gas as provided in Article 23 and Article 32 of Act No. 22 of 2001 on oil and Gas as well as Article 69 of Government Regulation Number 36 of 2004 on the downstream oil and gas business activities.

Transportation business must have permission from the Director of ESDM at least contains the name of the organizer, the type of business in the organization of the company, and the requisite technical loaded in accordance with Article 24 of Act No. 22 of 2001 on Oil and Gas. Commerce businesses must have permission from the Director of ESDM at least contain the name of the organizer, type of business, liabilitiesdalamholding company, and the terms of technical requirements in accordance with Article 23 of Act No.22 of 2001 on Oil and Gas. Based on the explanation of Article 53 of Act No. 22 of 200 l on Oil and Gas which by abusing the transport is an activity that aims to get benefit individuals or business concerns to the interest communities and countries such as, the activities of the mixing fuel oil, fuel oil deviations allocation, transportation and sale of Fuel abroad.

Circular Regent Purworejo as a reference for law enforcement in Purworejo. Purchase by using jerrycans should be a recommendation from Department of Industry, Trade and Cooperative District Purworejo, that the rules governing fuel for retailers Circular is the Regent, and in Circular is no classification for Mini gasoline. That to permit transport it in fact only aimed at filling stations for retailers large and fairly with any motorcycles and retailers are not required to permit transport but no maximum limit in this transport process is 20 liters per day.

The case has been investigated by the Police Purworejo suspects transporting the fuel that exceeds the provisions of Circular Regent Purworejo (over 20 liters) and have done offense without permission equipped transporting freight and commercial licenses can be presupposed has been misuse and abuse of the commercial transport of SBM is not subsidized as defined in Article 53 letters b and d of Republic Act No. 22 of 2001 on oil and gas.

\subsection{Analysis of Law Justice (Regional Aspects and Economic Aspects)}

The development of motor vehicles in Indonesia, particularly the development of two-wheel motor vehicles makes the supply of fossil fuels is increasing. The high fuel makes the fuel supply to the higher regions of Pertamina. Pertamina fuel supply in this area through a gas station (Fuel Filling Station General). This gas station into a formal point or an agent authorized to distribute fuel Pertamina to society. The retailer is not permitted in the regulations on the distribution of fuel is not subconfirmation but because of the area remote areas where infrastructure has not so difficult by BUPIUNU to distribute to the region then instituted the retailer in accordance with regulations of BPH Migas No. 6 of 2015 on fuel distribution and fuel certain special assignment.

Conditions hilly topography - hills and wide area especially in Purworejo make all supplies to areas not reachable by the pump. Gas stations in Purworejo still contained in the Urban Area with fuel retailers in many regions / Region Rural. In three years back retailers who use "bottles Herb" switch to a modern system using mini pumps and similar machines such as 
machine at the pump. This existence makes mini gas station business in the area, because it is convenient and modern look. The existence of mini gas station reap many of the weaknesses in the implementation of the field, this is because there is no standardization of the dosing system and security.

Rural communities / rural states require this fuel for daily activities - day, fuel is now a basic requirement for human activity. The emergence of the mini gas station / retailer becomes alternatf primary choice to make a purchase, because the proximity factor. The emergence of this gas station into a solution because the location of the official fuel stations away from residential / daily activities. Another problem in the system retailer / mini pom is a fuel distribution system to retail locations / mini gas station, because the transport system is done by each - still retailers using personal transport equipment motorcycle / car. These retailers purchase to the nearest gas station with a retail location. These purchases at the pump has a rule that only serve gas stations selling fuel (gasoline and diesel) only for transportation,

The principle of legal justice that offers solutions to the public should be considered, although there is a violation of rules that apply in this transport process. Legal clash between the needs of society with Section 53 letters b and d of Republic Act number 22 of 2001 on oil and gas must have an alternative way out of sync between the solution and the rule of law.The term justice (iustitia) is derived from the word "fair" which means: biased, impartial, favor the right, rightly, not arbitrary ${ }^{7}$ This justice is equality among members community in an act together. Equation is a point which lies between "more" and "the less "(intermediate). So justice is the mid point or a relative equation (Arithmetical justice) basic equations between community members highly dependent on the system living in that community

\section{Closing}

\subsection{Conclusion}

In the investigation and the trial verdict transport of fuel, investigators and judges to use the legal perspective based on the Act as well as the official rules in deciding the case. Almost all cases involving the transportation case sentenced. In sentencing investigator and judge using the Act No. 22 of 2011 on Oil and Gas.

The proliferation of this gas station this effort should be addressed with the applicable legal rules and legal justice in society. Legal aspects of becoming a formal requirement to provide a sense of security for the community. In terms of legal justice communities that have become staples of fuel every person at this time, due to aspect that can not be reached by the gas station / authorized agent of Pertamina. This inaccessibility makes the mini gas station / retailer present in society. The existence of the mini gas station / retailer has become one livelihood / economic factors. Fuel mini / reseller has no sales capacity of the pump. To supply this fuel will be purchased at the nearest gas station by using conductor. This process which involves a conflict of criminal law of oil and gas, for transporting the fuel system is not in accordance with the applicable rules. Factors transport capacity and safety factor included in a criminal act.

Cases that had occurred related to the transport system are buying in large quantities using a conductor in large quantities and brought four-wheeled vehicles. In addition the buyer does

\footnotetext{
${ }^{7}$ Departemen Pendidikan dan Kebudayaan 2001 Kamus Besar Bahasa Indonesia Balai Pustaka : Jakarta p.517
} 
not include the transport and purchase licenses that caused this case becomes a criminal offense. The transport system carried out by using a conductor and taken with four-wheel personal circumstances lead to insecurity of transportation of this fuel system.

To handle this case the Central Government / private maupaun area (Pertamina) must immediately make regulations to regulate the presence of the mini gas station / retailers and regulations regarding the transportation of this system. The central government through the Ministry of Energy and Mineral Resources. Kemenristek can standardize tools mini petrol station and transport tools to the transportation system of the mini fuel station. Pertamina as the private sector and suppliers of fossil fuels should be establishing partnership to make this gas station equipment which is in conformity with the standards of the dose and safety factors. Pertamina can optimize the vehicle ever in the era of the 2000s to supply kerosene entrance to the agents retailers in this village. Pertamina also can create an agent authorized distributor of fuel distribution to gas station mini, as is now being done to the distribution of LPG gas cylinders melon / 3-kg cylinder. The local government regulation that should be done is to make the decree related to the presence of this gas station, which includes a gas station mini safe site plan (plan layout tool mini petrol stations away from danger), the distance between the gas station mini etc. Besides the regional government must also record the number of the existence of the gas station mini regional

\subsection{Suggestion}

- The role of government is one important requirement in the prevention of distortion of the distribution of fuel

- Should the supervision of the distribution of the fuel by the police and relevant agencies more actively to supervise the implementation of the distribution of the fuel from the depot Pertamina to bases and communities participate in submitting the complaint to the police if it finds or suspects a case or perpetrators of deviation of the distribution of fuel oil

- Give sanction to see fairness laws and legislation in force so as to provide a solution in addressing this problem.

\section{Bibliography}

[1] Departemen Pendidikan dan Kebudayaan 2001 Kamus Besar Bahasa Indonesia Balai Pustaka : Jakarta

[2] Moeljatno L. 2015 Asas-asas Hukum Pidana Rineka Cipta : Jakarta

[3] Mukti Fajar dan Yulianto Achmad Dualisme Penelitian Hukum Penelitian Normatif \& Empiris Yogyakarta: Pustaka Pelajar 2010

[4] Salim HS dan Erlies Septiana Nurbani 2013 Penerapan Teori Hukum Pada Penelitian Penelitian dan Disertasi. Jakarta: PT Raja Grafindo Persada

[5] Soegijatno Tjakranegara 1995 Hukum Pengangkutan Barang dan Penumpang Rineka Cipta : Jakarta.

[6] Act No. 22 of 2001 on Oil and Gas 